Journal of Bangladesh Academy of Sciences, Vol. 37, No. 2, 189-193, 2013

\title{
USE OF ORGANIC AND INOGRANIC NUTRIENTS TO ENHANCE PRODUCTIVITY OF TURMERIC, CURCUMA LONGA L.
}

\author{
M.R. AMIN, M. ASADUZZAMAN, H. MEHRAJ, A. NUSRAT AND \\ A.F.M. JAMAL UDDIN* \\ Department of Horticulture, Sher-e-Bangla Agricultural University, Dhaka-1207, \\ Bangladesh
}

\begin{abstract}
This study on turmeric was conducted at Sher-e-Bangla Agricultural University, Dhaka during the period from April 2010 to March 2011. Five different fertilizer combinations were used in this experiment. Number of tiller per clump, weight of mother rhizome per plant, weight of primary and secondary finger per plant were significantly highest from $\mathrm{F}_{2}$ and lowest from $\mathrm{F}_{0}$. Highest turmeric yield per hectare $\left(11.6 \mathrm{t} / \mathrm{ha}\right.$ ) was obtained from $\mathrm{F}_{2}$ and the lowest $(5.7 \mathrm{t} / \mathrm{ha})$ was observed from $\mathrm{F}_{0}$.
\end{abstract}

Key words: Turmaric, Curcuma longa, Organic, Inorganic fertilizer, Productivity

\section{INTRODUCTION}

Turmeric (Curcuma longa L.) is a rhizomatous herbaceous perennial plant, important spice crop of the family, Zingiberaceae, grows to a height of about 1 to 1.8 meter and has deep orange fleshy roots or tubers. At present turmeric is widely cultivated throughout the tropics, but commercial production is concentrated in South-East Asia. In Bangladesh Rajshahi, Rangpur, Pabna, Kushtia, Jessore and Rangamati are the six districts which produce about $90 \%$ of whole production.

Gradual deficiency in soil organic matter and reduced yield of crops are alarming factors and burning issues for the farmers and agriculturists. All efforts should be made to develop consciousness of the farmers about the importance of soil organic matter and sustainable soil productivity for getting higher yield of crops. In recent years, poultry and livestock farming are boosting and supply of manure like poultry litter, cowdung etc. are increasing. Therefore, this work was undertaken to study the influence of chemical and organic fertilizers on growth and yield of turmeric as well as to find out the suitable combination of organic and inorganic fertilizes for the better productivity of turmeric.

\section{MATERIALS AND METHODS}

The present investigation was conducted in Horticulture Farm of Sher-e-Bangla Agricultural University, Dhaka, Bangladesh during the period from April, 2010 to March,

\footnotetext{
* Corresponding author: <jamal4@yahoo.com>.
} 
2011. In this study the local turmeric variety was collected from a Nursery, in Savar. The experiment consisted of various combination of organic and inorganic fertilizers; $\mathrm{F}_{0}$, Control (No fertilizer); $F_{1}, 2$ kg cow-dung + NPK (106g urea + 76g TSP + 68g MP) /plot; F, $1.2 \mathrm{~kg}$ poultry litter + NPK (106g urea + 76g TSP + 68g MP) /plot; $\mathrm{F}_{3}, 4 \mathrm{~kg}$ cow dung /plot; $\mathrm{F}_{4}, 3 \mathrm{~kg}$ poultry litter /plot. Each plot size was $2 \mathrm{~m} \times 2 \mathrm{~m}$. The experiment was laid out in Randomized Complete Block Design (RCBD) with three replications. The rhizome was planted maintaining $50 \mathrm{~cm} \times 25 \mathrm{~cm}$ spacing between and within the rows. The seed rhizome was planted at a depth of $7.5-8.0 \mathrm{~cm}$. Well-rotten cow dung (as treatment), dried poultry manure (as treatment), recommended doses of TSP (76 g/plot), MP (68 g/plot) and 50\% urea (106 $\mathrm{g} / \mathrm{plot}$ ) were applied during final preparation of plots. Rest $50 \%$ urea was applied in two equal installments at 90 and 120 days after transplanting (DAT) of turmeric rhizomes. Earthing up was done three times throughout the whole growing period. Data were collected on different yield contributing characters and yield.

The data obtained for different characters were statistically analyzed to find out the influences of different fertilizers on yield and yield contributing characters of turmeric. The mean values of all the recorded characters were evaluated and analysis of variance was performed by ' $F$ ' test. The significance of the difference among the treatment combinations of means was estimated by Duncan's Multiple Range Test at the $5 \%$ level of probability (Gomez and Gomez 1984).

\section{RESULTS AND DISCUSSION}

Plant height: Plant height of turmeric was measured at of 60, 90, 120, 150, 180 and 210 DAT. At all these times, tallest plant was observed from $\mathrm{F}_{2}$ which was statistically similar to $\mathrm{F}_{1}$ treatment. Shortest plants were found from $\mathrm{F}_{0}$ at all days after transplanting (Fig. 1).

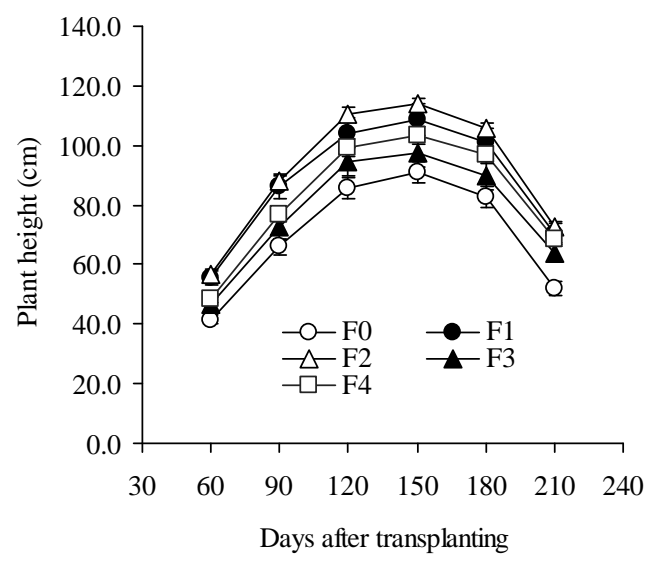

Fig. 1. Effects of different fertilizer combinations on plant height at days after transplanting (DAT) of turmeric. 
Number of leaves per plant: Due to the application of different fertilizers, the number of leaves per plant of turmeric differed at different days after transplantation. At all the six DAT, the maximum numbers of leaves per plant were observed from $\mathrm{F}_{2}$ which was statistically similar with $\mathrm{F}_{1}$, respectively. Minimum number of leaves was found from $\mathrm{F}_{0}$ which was statistically similar with $\mathrm{F}_{3}$, at all six DAT (Fig. 2). It was revealed that with the application of fertilizers, number of leaves per plant increased up to a certain days, then decreased due to the senescence of leaves at maturity stage.

Number of tillers per clump: Number of tillers per clump of turmeric differed due to the application of different fertilizers. Maximum number of tillers per clump was recorded from $F_{2}$ which was statistically identical with $F_{1}$ (Table 1). Again, the minimum number of this parameter was found from $\mathrm{F}_{0}$, which was closely followed by $\mathrm{F}_{3}$. It was noted that with the increase of nutrient content, the number of tillers per clump increased.

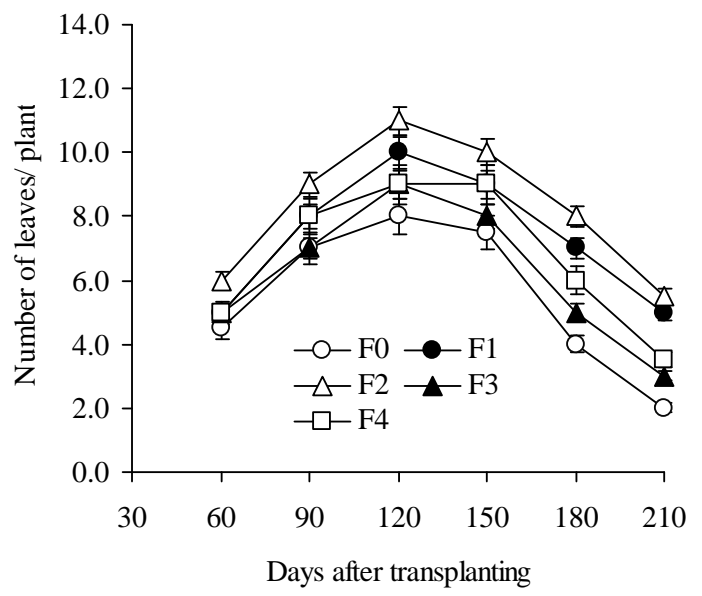

Fig. 2. Effects of different fertilizer combinations on number of leaves per plant at days after transplantation (DAT) of turmeric.

Leaf length: Highest leaf length was observed from $\mathrm{F}_{2}$ which was statistically similar to $F_{1}$ and the lowest was observed from $F_{0}$ (Table 1). It revealed that fertilizer helped for optimum vegetative growth that ensured maximum leaf length. Medda and Hore (2003) recorded longest leaf length from highest amount of nutrient from their earlier experiment.

Leaf breadth: Leaf breadth of turmeric varied due to the application of different fertilizers. The maximum leaf breadth was recorded from $\mathrm{F}_{2}$ which was closely followed by $F_{1}$. The lowest breadth was observed from $F_{0}$ (Table 1). It revealed that the leaf breadth increased with the increased level of nutrient supplement due to optimum cell size. 
Weight of mother rhizome per plant: Weight of mother rhizome per plant of turmeric differed due to the application of different fertilizers. Highest weight of mother rhizome per plant was recorded from $\mathrm{F}_{2}$. The lowest was found from $\mathrm{F}_{0}$ (Table 1). It was revealed that weight of mother rhizome increased with the increased amount of fertilizers. Poultry litter ensured maximum plant nutrients in available form which helped proper growth of plant resulting highest weight of mother rhizome.

Table 1. Effects of different fertilizers on yield and yield contributing parameters of turmeric.

\begin{tabular}{|c|c|c|c|c|c|c|c|c|c|}
\hline \multirow[b]{2}{*}{ Treatment } & \multirow{2}{*}{$\begin{array}{l}\text { Number } \\
\text { of tiller } \\
\text { /clump }\end{array}$} & \multirow{2}{*}{$\begin{array}{c}\text { Leaf } \\
\text { length } \\
(\mathrm{cm})\end{array}$} & \multirow{2}{*}{$\begin{array}{c}\text { Leaf } \\
\text { breath } \\
(\mathrm{cm})\end{array}$} & \multirow{2}{*}{$\begin{array}{l}\text { Wt. of } \\
\text { mother } \\
\text { rhizome/ } \\
\text { plant }\end{array}$} & \multicolumn{2}{|c|}{ Primary finger } & \multicolumn{2}{|c|}{ Secondary finger } & \multirow{2}{*}{$\begin{array}{l}\text { Yield } \\
(\mathrm{t} / \mathrm{ha})\end{array}$} \\
\hline & & & & & Number & $\begin{array}{l}\text { Weight } \\
\text { (g) }\end{array}$ & Number & $\begin{array}{l}\text { Weight } \\
(\mathrm{g})\end{array}$ & \\
\hline $\mathrm{F}_{0}$ & $1.4^{\mathrm{d}}$ & $37.3^{\mathrm{c}}$ & $10.6^{\mathrm{c}}$ & $21.3^{\mathrm{c}}$ & $4.4^{\mathrm{b}}$ & $43.6^{\mathrm{d}}$ & $7.7^{\mathrm{c}}$ & $32.2^{\mathrm{c}}$ & $5.7^{\mathrm{d}}$ \\
\hline $\mathrm{F}_{1}$ & $2.0^{\mathrm{b}}$ & $44.3^{\mathrm{a}}$ & $12.2^{\mathrm{a}}$ & $30.5^{\mathrm{b}}$ & $5.5^{\mathrm{ab}}$ & $54.7^{\mathrm{b}}$ & $10.6^{\mathrm{ab}}$ & $45.5^{\mathrm{ab}}$ & $9.6^{\mathrm{b}}$ \\
\hline $\mathrm{F}_{2}$ & $2.2^{\mathrm{a}}$ & $45.3^{\mathrm{a}}$ & $12.5^{\mathrm{a}}$ & $35.8^{\mathrm{a}}$ & $6.1^{\mathrm{ab}}$ & $66.6^{\mathrm{a}}$ & $11.8^{\mathrm{ab}}$ & $50.9^{\mathrm{ab}}$ & $11.6^{\mathrm{a}}$ \\
\hline $\mathrm{F}_{3}$ & $1.7^{\mathrm{c}}$ & $42.4^{\mathrm{ab}}$ & $11.8^{\mathrm{abc}}$ & $23.9^{\mathrm{c}}$ & $5.2^{\mathrm{ab}}$ & $51.2^{\mathrm{bc}}$ & $9.6^{\mathrm{abc}}$ & $41.4^{\mathrm{b}}$ & $8.3^{\mathrm{c}}$ \\
\hline $\mathrm{F}_{4}$ & $1.8^{\mathrm{c}}$ & $39.2^{\mathrm{bc}}$ & $11.3^{\mathrm{bc}}$ & $26.4^{\mathrm{bc}}$ & $5.1^{\mathrm{ab}}$ & $48.1^{\mathrm{c}}$ & $8.9^{\mathrm{bc}}$ & $36.7^{\mathrm{bc}}$ & $7.8^{\mathrm{c}}$ \\
\hline LSD (0.05) & 0.1 & 3.9 & 1.1 & 4.3 & 1.1 & 5.2 & 2.6 & 5.4 & 1.1 \\
\hline $\mathrm{CV}(\%)$ & 9.2 & 8.6 & 6.9 & 7.5 & 9.7 & 8.2 & 7.8 & 10.4 & 7.6 \\
\hline
\end{tabular}

See materials and Methods for these symbols. In the vertical columns means having similar letter are statistically non-significant at $5 \%$ level.

Number of primary finger per plant: Number of primary finger per plant of turmeric differed due to the application of different fertilizers. Highest number of primary finger per plant was recorded from $\mathrm{F}_{2}$ and the lowest from $\mathrm{F}_{0}$ (Table 1).

Weight of primary fingers per plant: Weight of primary finger per plant of turmeric differed due to the application of different fertilizers. Highest weight of primary finger per plant was recorded from $\mathrm{F}_{2}$. Again, the lowest was observed from $\mathrm{F}_{0}$ (Table 1). It revealed that the weight of primary finger increased with the increase in nutrient content.

Number of secondary finger per plant: Number of secondary fingers per plant of turmeric differed significantly due to the application of different fertilizers. The highest number of secondary finger per plant was found from $\mathrm{F}_{2}$, which was statistically similar to $F_{1}$ and the lowest was observed from $F_{0}$ (Table 1). Similar trends of results were also reported by Patra (1998).

Weight of secondary fingers per plant: Due to the application of different fertilizers, weight of secondary fingers per plant in turmeric varied. The highest weight of secondary finger per plant was found in $F_{2}$, which was statistically similar to $F_{1}$. The lowest was observed in $\mathrm{F}_{0}$ (Table 1). 
Yield per hectare: Yield per hectare of turmeric differed significantly due to the application of different fertilizers used. Highest yield per hectare was obtained from $\mathrm{F}_{2}$. The lowest yield per hectare was observed in $\mathrm{F}_{0}$ (Table 1). Organic manures improved the root system of turmeric, so the roots could absorb the minerals and irons from soil solution efficiently, resulting in higher yield.

\section{CONCLUSIONS}

Both organic and inorganic fertilizers showed significant variations with yield and yield contributing characters. But poultry liter with recommended dose of NPK gave the best results.

\section{REFERENCES}

Gomez, K. A. and A. A. Gomez. 1984. Statistical Procedure for Agricultural Research ( $2^{\text {nd }}$ edn.), $A$ Willey Int. Sci. pp. 28-192.

Medda, P. S. and J. K. Hore. 2003. Effect of N and K on the growth and yield of turmeric in alluvial plains of West Bengal. Indian J. Hort. 60(1): 84-88.

Patra, S. K. 1998. Fertilizer management in turmeric (Curcuma longa L.) under rainfed farming system. Envir. Ecol. 16(2): 480-482.

(Received revised manuscript on 5 July, 2013) 